\title{
Veri Zarflama Analizi ile Firma Değerleme Yaklaşımı Borsa İstanbul Gıda Sektörü Örneği
}

\begin{tabular}{|} 
Nevzat AYPEK ${ }^{1}$ - Yusuf Ozan ÜZGÜN ${ }^{2}$ \\
\hline$\frac{\text { Gönderim Tarihi }}{16.07 .2021}$ & $\frac{\text { Kabul Tarihi }}{05.10 .2021}$ \\
\hline
\end{tabular}

\section{Önerilen Atıf / Suggested Citation:}

Aypek, N. \& Üzgün, Y. O. (2022). Veri Zarflama Analizi ile Firma Değerleme Yaklaşımı Borsa İstanbul Gıda Sektörü Örneği. Bankacılık ve Finansal Araştırmalar Dergisi, 9(1), 1-19.

\section{$\ddot{O} z$}

Klasik değerleme metotlarının yanı sira, değerleme uzmanlarının kullanabileceği yeni değerleme metotlarının geliștirilmesinin önemli olduğu değerlendirilmektedir. Veri zarflama analizi(VZA) de, firma değerlemesinde kullanılabilecek alternatif bir yaklaşım olarak çımaktadır. VZA genellikle verimli ve verimsiz organizasyonel birimleri, bir diğer deyişle karar verme birimlerini (KVB) bulmak için kullanılmakta olup, verimsiz KVB'lerin kendilerini örnek aldıları akran KVB'lerin bulunması için de kullanılabilecek bir araçtır. Bu çalışmada da öncelikle literatürde yer alan çalı̧̧malardan elde edilen bilgiler yardımıyla VZA'nın akran bulma özelliğinden faydalanarak verimsiz firmaların piyasa değer aralıklarının ve üst sınır değerinin nasıl tahmin edilebileceği açıklanmış, akabinde de daha önce yapılan çalışmalar örnek alınarak BIST Gıda Sektörü firmaları için bir uygulama yapılmıştır. Uygulama neticesinde, VZA için yeter saylda karar verme birimi analize dâhil edilmişs olmasına rağmen, verimsiz firmalar için yeterli sayıda karşılaş̧tırlabilir firma bulunamamıştır. Bu da, değer aralı̆̆l tahmininin tatmin edici sonuçlar vermemesine yol açmıştır. Diğer taraftan, az sayıda karşılaş̧tırllabilir firma olmasına rağmen verimsiz firmaların üst sinır değerlerinin bulunmasinda daha tatmin edici bulunmuştur. Uygulamada gördüğ̈̈müz bu sonuçlar değerlendirildiğinde, VZA ile değerleme çalışmasından daha iyi sonuç alabilmek için çok daha yüksek saylda KVB'nin kullanılması gerektiği, böylelikle de daha fazla akran firma bulunabileceği ve daha hassas değer aralıklarının tespit edilebileceği anlaşılmıştır.

Anahtar Kelimeler: Değerleme, Veri Zarflama Analizi, Piyasa Esaslı Değerleme Yaklaşımı, BIST Gıda Sektörü

Jel Kodlart: G17, G32

\section{Firm Valuation Approach with Data Envelopment Analysis Borsa İstanbul Food Industry Example}

\begin{abstract}
In addition to classical valuation methods, it is considered important to develop new valuation methods that can be used by professional appraisers. Data envelopment analysis (DEA) emerges as an alternative approach that can be used in firm valuation. DEA is generally used to find efficient and inefficient organizational units, in other words, decision making units (DMUs), and it is a tool that can be used to find peer DMUs that inefficient DMUs take as examples. In this study, first of all, with the help of the information obtained from the studies in the literature, it is explained how the market value ranges and upper limit values of inefficient firms can be estimated by use of the peer finding feature of DEA, subsequently, an application was made for BIST Food Sector companies by taking the previousy conducted studies as an example. As a result of the application, although sufficient number of decision-making units were included
\end{abstract}

\footnotetext{
${ }^{1}$ Prof. Dr., Ankara Hacı Bayram Veli Üniversitesi İktisadi ve İdari Bilimler Fakültesi İşletme Bölümü, nevzat.aypek@hbv.edu.tr, https://orcid.org/0000-0002-0780-9975

2 ozanuzgun@hotmail.com, https://orcid.org/0000-0002-2667-7779
} 
in the analysis for DEA, sufficient number of comparable firms could not be found for inefficient firms. This situation caused the value range estimation not to give satisfactory results. On the other hand, although there are few comparable firms, it is more satisfactory to find the upper bound values of inefficient firms. When these results we have seen in practice are evaluated, it is understood that a much higher number of DMUs should be used in order to get better results from the DEA valuation study. Thus, more peer companies can be found and more sensitive value ranges can be determined.

Keywords: Valuation, Data Envelopment Analysis, Market Based Valuation Approach, BIST Food Sector

Jel Codes: G17, G32

\section{Giriş}

Firma değerlemesi kısaca ifade edilmek istenirse ekonomilerin can kaynağı olan firmaların gerçek değerinin bulunması için yapılan faaliyetler bütünüdür. Özellikle son yıllarda, sermaye piyasalarının gelişmesi ve derinleşmesi sonucunda hisse senetlerinin değerlemesi konusu daha da önem kazanmıştır. Alıcı ve satıcılar, borsalarda hisseleri işlem gören firmaların gerçek değerinin ne olduğunu bilmek istemekte ve bu bilgi doğrultusunda alım satım kararları almaktadırlar. Değerleme işlemleri, menkul kıymet borsalarındaki kullanımı ile sınırlı kalmaksızın, örneğin özelleştirme faaliyetlerinde özelleştirilecek şirketlerin değerlemesinde, şirket birleşme ve devirlerinde, firmaların kendi değerlerini arttırma çabaları kapsamında alacakları kararların belirlenmesi gibi birçok alanda kullanılmaktadır.

Firma değerlemesine ilişkin literatür incelendiğinde, değerlemenin uzun yıllar boyunca belirli yaklaşımlar çerçevesinde şekillendiği görülmektedir. Bu yaklaşımlardan en çok kabul göreni firmanın gelecekteki nakit akışlarının bugüne indirgenmesi suretiyle firma değerinin bulunmasıdır. Bunun yanında piyasa bazlı değerleme olarak da adlandırılmakta olan bir diğer değerleme yaklaşımında, değerlemesi yapılacak şirketin piyasadaki benzer firmalar ile karşılaştııılması yapılmakta ve değeri aranan firmanın piyasa değeri benzer firmaların piyasa değerine göre belirlenmektedir.

Klasik değerleme metotlarının yanı sıra, değerleme uzmanlarının kullanabileceği yeni değerleme metotlarının geliştirilmesi önemlidir. Veri zarflama analizi de, firma değerlemesinde kullanılabilecek alternatif bir yaklaşım olarak karşımıza çıkmaktadır.

Esas olarak Farrell'in performans etkinliğini belirlemedeki teorik yaklaşımına dayanan Veri Zarflama Analizi, Charnes ve diğerleri tarafından geliştirilmiş doğrusal programlama tabanlı bir yaklaşım olup, geçen yıllar içerisinde farklı VZA modelleri ve gerçek hayat uygulamaları yaygın olarak kullanılmıştır (Ulucan, 2002, s.187).

VZA bir çok alanda kendisine kullanım alanı bulabildiği gibi piyasa bazlı değerleme yaklaşımları kapsamında firma değerlemesinde de kullanılabilmekte olup, buna ilişkin kısıtlı sayıda da olsa örnekler mevcuttur. Bu çalışmanın amacı, VZA ile değerlemenin teorik altyapısı hakkında bilgi vermek ve Türkiye'deki firma verilerini kullanarak örnek bir çalışma yapmak suretiyle, değerleme uzmanlarına alternatif bir değerleme yöntemi sunabilmektir.

\section{Yöntem}

Dünya literatüründe, veri zarflama analizinin firma değerlemesinde kullanımına ilişsin kısıtlı sayıda çalışma bulunduğu görülmekle birlikte, Türkçe literatürde bu yöntemin değerlemede kullanımına ilişkin bir çalışmaya rastlanmamıştır. Esas olarak, çalışmanın öneminin de buradan kaynaklandığı düşünülmekte ve çalışma ile Türkiye' de henüz kullanılmamış bir yöntem ile firma değerlemesi yapmanın ve bunu yaparken de yöntemin geliştirilebilecek yönlerinin araştırılmasının önemli olduğu değerlendirilmektedir. 
Bu çalışmada öncelikle firma değerlemesi, piyasa esaslı değerleme yaklaşımı, VZA'nın yapısı ve matematiksel gösterimi ele alınmış devamında VZA ile firma değerlemesine ilişkin literatür taraması sonuçları sunulmuştur. Teorinin ardından, Ms. Excel yardımıyla girdi ve çıktılarının korelasyon katsayısı hesaplanan ve Efficiency Measurement System adlı program yardımıyla Borsa İstanbul Gıda Sektörü firmalarının veri zarflama analizi ile değerlemesine ilişkin örnek bir uygulama yapılmış ve değerleme uygulayıcılarına veri zarflama analizi yapmak suretiyle değerleme uygulaması yaparken örnek alabilecekleri çalışma sunulmuştur.

\section{Firma Değerlemesi}

Değerleme, bir varlığın veya yükümlülügün değerinin tahmin edilmesi sürecidir (International Valuation Standards Council, 2020). Firma değerlemesi ile genelde ifade edilmek istenen ise firmanın borç ve öz kaynaklarının cari tutarlarının (aktiflerin) toplam değerinin bulunmasıdır. Bu değer, firmanın maddi duran varlıklarının değeri ile maddi olmayan varlıklarının değerlerinin toplamından oluşmaktadır. Hissedarlar açısından ele alındığında ise firma değeri, firmanın varlıklarının cari değerinden, borçlarının cari değerlerinin düşülmesi ile bulunan özsermaye değeridir (Ercan, Öztürk ve Demirgüneş, 2003, s.1).

Firma değerlemesinin esas amacı şirketin uygun ve makul piyasa değerinin tespitidir. Modern finans teorisinde genel kabul görmüş teoriye göre firmanın değeri, gelecekte sağlayacağı nakit akışlarının indirgenmiş bugünkü değeridir. Dolayısıyla da, temelde firma değeri, firmanın gelecekte sağlayacağı nakit akışlarına ve bunların elde edilmesindeki risk derecesine bağlıdır (Öztürk, 2009, s.26-27).

Firmaların genel amacının hissedar değerini maksimize etmek olduğu (Copeland, 1994, s. 97109) dikkate alındığında "değerleme" konusunun önemi daha iyi anlaşılabilecektir. Değerleme esas olarak finansın kalbi niteliğini taşımaktadır. Kurumsal finansda yatırım, finansman ve temettü kararlarını vererek firma değerini en iyi nasıl artırabileceği konusu değerlendirilmektedir. Portföy yönetiminde, kaynakları gerçek değerlerinden daha düşük bir seviyede işlem gören firmaların bulunarak yatırım yapılması ve bunların gerçek değerine yaklaşması ile kar elde edilmesi amaçlanır. Piyasaların verimli olup olmadığını incelerken, piyasa fiyatlarının değerlerinden sapıp sapmadığı ve eğer öyleyse ne kadar hızlı geri döndükleri analiz edilmektedir. Bir firmanın değerini neyin belirlediğini ve bu değerin nasıl tahmin edileceğini anlamak, mantıklı kararlar almak için bir önkoşul gibi görünmektedir (Damodaran, 2006, s. 3).

Finans literatüründe çok basit yöntemlerden başlayarak daha karmaşık yöntemlere uzanan birçok değerleme yöntemi kullanılmakla birlikte, bu yöntemlerden bazıları ortak birtakım özellikler taşıdıklarından bir arada sınıflandırılmaktadır. Ortak özellik taşıyan bu değerleme yöntemlerinin bir arada sınıflandırılmasıyla birlikte daha geniş bir kavram olan "değerleme yaklaşımı" kavramı ortaya çıkmıştır (Sipahi, Yanık, Aytürk, 2016, s.25). Yine, her değerleme yaklaşımının içerisinde, değeri belirlemek için kullanılan birçok yöntem bulunmaktadır.

Çalışmanın uygulama aşamasında kullanılacak olan Veri Zarflama Analizi ile firma değerlemesi, esas olarak bir piyasa esaslı değerleme yaklaşımının bir parçası olarak görüldüğünden, burada da bu yaklaşım üzerinde durulacaktır.

\subsection{Piyasa Esaslı Değerleme Yaklaşımları}

Piyasa esaslı değerleme yaklaşımının ana prensibi neoklasik iktisat yaklaşımının doğrudan çıktısı olup bu prensip bir firmanın değerinin piyasada kendisine benzeyen firmaların değerine bağlı olmasidir (Anderson, 2012, s.203).

Piyasa esaslı değerleme yaklaşımının temelinde, firma değerinin aynı özelliklere sahip karşılaştırılabilir firmalara ait veriler kullanılarak tespit edilmesi yatmaktadır. Göreceli 
değerleme olarak da adlandırılan bu yöntemde, değeri tespit edilmek istenen firmanın değeri, kazançlar, nakit akımları, defter değerleri ya da satışlar gibi değişkenlere bağlı olarak, karşılaştırılabilir firmaların değerleri dikkate alınmak suretiyle hesaplanmaktadır. Genellikle halka açık olmayan firmaların değerinin tespitinde bu değerleme yöntemi kullanılmakta olup, karşılaştırılabilir firmalar ise genellikle halka açık ve karşılaştırma yapılan firma ile aynı sektörde faaliyet gösteren firmalardır (Ercan ve Diğ. , 2003, s.43).

Piyasa esaslı değerleme yaklaşımı kapsamında kullanılan en yaygın değerleme yöntemleri "fiyat/kazanç oranı" yöntemi, "piyasa değeri/defter değeri oranı" yöntemi, "şirket değeri / FAVÖK (EBITDA) oranı yöntemi” dir.

Yaygın bir şekilde kullanılan bu yaklaşımın en büyük avantajı kolay anlaşılır ve kolay uygulanabilir olmasıdır. Yine, değer tahmininde gerçek verilerin kullanılıyor olması, değerleme sürecinde işletmenin maddi ve maddi olmayan varlıklarının tamamının değerinin dikkate alınması ve tarihi veriler yerine piyasa değerlerini kullanması da yöntemin diğer avantajlarıdır.

Piyasa yaklaşımının göze çarpan en zayıf noktası, çoğu firmanın özkaynaklarının nadir olarak bir pazarda işlem görmesi nedeniyle karşılaştırılabilir firmaların tespitinde yaşanabilecek zorluktur (Anderson, 2012, s.203). Karşılaştırılabilir şirket, nakit akışları, büyüme potansiyeli ve riski, değerleme yapılacak olan şirketle benzer olan şirkettir (Sipahi, Yanık ve Aytürk, 2016, s.124). Değerlenecek şirkete ait bu değerlerin, aynı sektörde yer alan şirketlere benzediği kabulü ile karşılaştırılabilir şirketler genellikle aynı sektörde faaliyet gösteren şirketlerden seçilmektedir.

Değerin tahmininde tutarsız sonuçlara ulaşılabilmesi, yöntemin diğer yaklaşımlar kadar esnek ve adapte edilebilir olmaması, varsayımlarının (risk, marjlar, büyüme oranı) açık olmaması ve bu varsayım parametrelerinin karşılaştırılabilir firmaların oranlarının fonksiyonu olması bu yöntemin diğer dezavantajlarıdır (Ercan ve Diğ, 2003, s.45).

Piyasa esaslı değerleme yaklaşımındaki, firmaların faaliyetlerindeki karşılaştırılabilir parametrelerinin bulunmasındaki ve benzer firmaların tespitindeki zorlukların aş1labilmesi noktasında VZA, firmalar arasında çok boyutlu bir karşılaştırmaya izin veren bir yöntem olarak değerlendirilmektedir.

Aşağıda piyasa esaslı değerleme yaklaşımı kapsamında karşılaştırılabilir firmaların bulunması amacıyla işbu çalışmaya

katk1 sağlayacak olan Veri Zarflama Analizi üzerinde durulacaktır.

\section{Veri Zarflama Analizi}

Veri Zarflama Analizi (VZA) (Data Envelopment Analysis-DEA), benzer işler yapan, çoklu girdi/çıktıya sahip organizasyonel birimlerin göreli etkinliklerini ölçmede kullanılan matematiksel programlama tabanlı bir tekniktir. Özellikle, birden fazla girdi ya da çıktının, ağırlıklı bir girdi ya da çıktı setine dönüştürülemediği durumlarda VZA etkin bir yaklaşım olarak kabul görmüştür (Ulucan, 2002, s.186-187).

VZA yöntemi, doğrusal programlama temelli, üretim fonksiyonunun tespit edilmesine ihtiyaç duymayan yani parametrik olmayan bir yöntem olup, yöntemin bu özelliği VZA'yı diğer etkinlik ölçme yöntemlerinden ayırmaktadır (Yakut ve Kuru, 2019, s.11-31).

VZA'da karar birimleri, istatistiksel yöntemlerde olduğu gibi ortalama verimlilikle değil, en verimli birime göre kıyaslama yapılarak gerçekleştirilmekte olup, VZA'nın bu özelliği göz önüne alındığında bu yöntem bir uç sınır tekniği olarak da adlandırılabilir (Yücel, 2017, s.1).

Veri Zarflama Analizi, Charnes ve diğerleri (1978) tarafından geliştirilmiş doğrusal programlama tabanlı bir yaklaşım olup, geliştirildiği yıldan bu yana farklı VZA modelleri ve gerçek hayat uygulamaları yaygın olarak kullanılmaktadır (Ulucan, 2002, s.187). 
VZA tekniği, bir sınır (frontier) belirlemek suretiyle, karşılaştırma kümesi içerisinde yer alan her bir organizasyonun verimliliğini bu sınıra uzaklığına göre göreceli analiz etmektedir. VZA, gözlemlenen girdi ve çıktıları kullanarak, ağırlıklı çıktıların ağırlıklı girdilere oranı olarak hesaplayarak her bir karar biriminin göreli etkinliğini belirler. Bu yöntem, geleneksel yöntemlerin çoklu girdi ve çoklu çıktıların değerlendirilmesi için sağlayamadıkları bütünselliği, toplam faktör verimliliği mantığı ile sağlayabilmektedir. VZA tekniğinde girdi ve çıktıların ağırlıkları karar verme birimleri için kendi etkinlik oranlarını maksimize edecek şekilde kullanılmaktadır. A ğırlıklar her bir karar verme biriminin girdi ve çıktıları için ayrı ayrı tahsis edilir. VZA'nın bu esnekliğinin VZA için ana avantajlardan biri olduğu söylenebilir (Kutlar ve Babacan, 2008, s.150).

VZA ile ayrıca karar verme birimlerine referans oluşturacak birimler bulunabilmektedir. Yine bu çerçevede, etkinlik sınırının altında kalan birimler için iyileştirici tavsiyelerde bulunabilmektedir (Kutlar ve Bakırc1, 2018, s.127-128).

Verimlilik ölçümünde, klasik olarak çıktının girdiye oranlanması yöntemi basit olması nedeniyle hızlı çözümler sunabilmektedir. Ancak, çok girdili ve çok çıktılı üretim süreçlerinin verimliliklerinin ölçülmesinde basit oran yaklaşımı yetersiz kalmaktadır. Hesaplaması yapılan bir çıktı/girdi oranına göre verimli gibi görülen bir birim, başka bir çıktı/girdi oranına göre verimsiz gibi görünebilmektedir. Basit verimlilik ölçümünün bu sakıncasını ortadan kaldırmak üzere toplam faktör verimliliği (Total Factor Productivity-TFP) kavramından istifade edilmekte olup, toplam faktör verimliliğinde, üretim sürecinin girdileri toplanarak tek bir girdi faktörüne (sanal girdi) ve çıtıların toplamı da tek bir çıktı faktörüne (sanal çıktı) indirgenmektedir. Daha sonra toplam girdi ve toplam çıktı faktörlerinin oranına bakılarak değerlendirme yapılmaktadır. $\mathrm{Bu}$ yaklaşımın zayıf noktası, farklı özellikteki girdi ve çıktı faktörlerinin nasıl toplanacağı konusunda herhangi bir ipucu verememesidir. Diğer bir deyişle, faktörler için uygulanacak olan katsayıların bilinmiyor olmasıdır ancak VZA analizi bu katsayıların bulunmasında yeni bir açılım getirmiştir (Tarım, 2001, s.12-13).

VZA modellerinden en geniş uygulama alanına sahip olanlar Charnes, Cooper ve Rhodes (1978)'un geliştirdiği CCR modeli ile Banker, Charnes ve Cooper (1984) tarafından geliştirilen BCC modelleri olup, CCR modeli ölçeğe göre sabit getiri varsayımı ile toplam etkinliğin ölçümünün yapılmasını sağlarken, BCC modeli ise ölçeğe göre değişken getiri varsayımı altında teknik etkinliği ölçmektedir (Özçelik ve Avcı Öztürk, 2019, s.1017).

CCR ve BCC modellerinin her birinin kendi altında, girdi yönlü ve çıktı yönlü olmak üzere iki temel modeli bulunmaktadır. Girdi yönlü VZA modeli, sınırlı bir çıktı bütününü en verimli biçimde üretebilmek için kullanılacak en uygun girdi bütünün üzerinden hesaplamalarını yaparken, çıktı yönlü VZA modeli ise sınırlı bir girdi bütünü ile maksimum ne kadar çıktı üretilebileceği üzerinden hesaplamalarını gerçekleştirir (Özdemir ve Göktaş, 2019, s.142).

Avantajlarının yanı sıra, VZA modelinin sınırlı kaldığı bazı alanlar mevcuttur. Her şeyden önce, VZA'nın nispi verimlilik skorlaması modelin önemli bir sınırlaması olarak karşımıza çıkmaktadır. VZA sürecinde en iyi performans gösteren birimler yüzde yüz verimli olarak kabul edilir. VZA, verimlilik sınırı oluşturmak ve birimlerin verimliliğini buna göre değerlendirmek için en iyi performansı gösteren birimleri kullanır. Bu nedenle, verimliliği ideal veya ortalama yerine en iyi performans gösteren birimlere dayandırmak modelin bir sınırlaması olarak düşünülebilir. Göreceli verimlilik puanlaması nedeniyle, VZA en iyi performans gösteren birimlerin verimsizliklerini otomatik olarak yok sayar ve bunları tamamen verimli olarak kabul eder (Tümer, 2008, s.91-92). Diğer taraftan, VZA, parametrik olmayan bir yöntem olduğundan, sonuçlarına istatistiksel hipotez testleri uygulanamaz (Çam ve Sulak, 2019, s.44). Dolayısıyla, gözlenen farklılıkların anlam seviyeleri istatistiksel olarak açıklanamaz (Demirci, 2018, s.63).

Yine, etkinliğin uzun dönemde belirlenebileceği bazı yatırım alanlarında VZA ile etkinlik ölçmek olumsuz sonuçlara yol açmaktadır. Zira, bir girdinin etkinlik sonuçları sonraki dönemlerde alınabilecekse, sadece o dönem için bir analiz yapmak gerçekçi bir sonuç vermeyecektir. Çünkü, 
VZA modelleri statik yapıda olup, tek dönemde değerlendirilen modellerdir. Gerçek hayatta ise karar verme birimlerinin bazı girdilerini çıtılara dönüştürebilmesi daha uzun bir süre alabilmektedir. Zira, üretim süreci dinamik bir yapıya sahiptir (Kutlar ve Bakırc1, 2018 s. 188189).

\subsection{VZA Modelinin Matematiksel Yapısı}

Girdiye yönelik ve çıktıya yönelik olmak üzere iki yönlü kullanılabilen VZA modellerinin her birisi kendi içinde oransal, ağırlıklı ve zarflamalı olmak üzere düzenlenmektedir. Girdiye yönelik oransal model, VZA'nın esas yapısını oluşturmaktadır. Bu modele göre her bir birim, diğer gözlemlerle karşılaştırılır ve etkinlik düzeyleri belirlenir. Ağılıklı model de, oransal modelin doğrusal programa çevrilmiş halidir. Doğrusal programlamanın amaç fonksiyonunun paydalı şekilde olması mümkün olmadığından, bu maksatla, oransal modeldeki amaç fonksiyonunun paydası 1'e eşitlenir. Son olarak zarflamalı modelde ağırlıklı modelin duali alınarak elde edilir. Zarflama modelinde, radyal olarak ölçülemeyen fakat azaltılması veya arttırılması mümkün olan atıl girdi ve çıktı vektörlerinin hesaplanması mümkündür. Böylece incelenen birimlerin hangi girdi ve/veya çıktısının ne oranda kullanılmadığı da görülmüş olmaktadır. Ayrıca bu modelde, ağırlıklı modele göre referans kümesinin bulunması daha kolaydır (Demirci, 2018, s.33).

\subsubsection{CCR Model}

Bu model ölçeğe göre sabit getiri varsayımına dayanmakta olup, bir birimlik girdi artışının (veya azalışının), bir birimlik çıktı artışına (veya azalmasına) sebep olduğu varsayımına dayanmaktadır. Diğer tüm VZA modelleri gibi doğrusal programlamayı esas almaktadır. İlk VZA modeli olan CCR, toplam faktör verimliliğinden yola çıkılarak ağırlıklı toplam çıktıların ağırlıklı toplam girdilere oranlanması ile türetilmiştir. Doğrusal programlama formuna dönüşüm, kesirli (oransal) formdaki modele dönüşüm yapılması suretiyle elde edilmiş olup, doğrusal forma geçmeden önce, modelin kesirli yapısının açıklanması daha uygun olacaktır (Yücel, 2017, s.21).

VZA'da $\mathrm{n}$ adet karar verme biriminin her birisine ait $\mathrm{m}$ adet girdi ve $\mathrm{s}$ adet çıktı varsa, j'inci girdi miktarı $X X_{i i i i} \geq 0$ vej'inci karar verme birimi tarafından üretilen r'inci çıktı miktarı $Y Y_{\text {rrï }} \geq 0$ olmak üzere, girdi yönelimli kesirli VZA modeli;

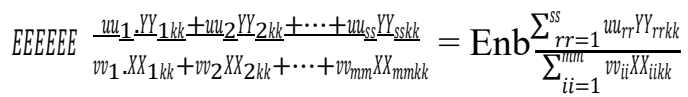

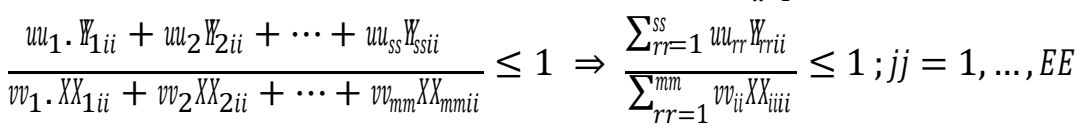

$$
\begin{aligned}
& u u_{r r} \geq \varepsilon \varepsilon \geq 0 ; r r=1 \ldots ., s s
\end{aligned}
$$

$v v_{i i} \geq \varepsilon \varepsilon \geq 0 ; \mathrm{I}=1, \ldots, \mathrm{m}$

biçiminde gösterilir. Modelde

Enb : Enbüyükleme

$\mathrm{u}_{\mathrm{r}} \quad: \mathrm{k}$ karar birimi tarafından r'inci çıktıya verilen ağırlık,

$\mathrm{V}_{\mathrm{i}} \quad: \mathrm{k}$ karar verme birimi tarafından i'inci girdiye verilen ağırlık,

$\mathrm{Y}_{\mathrm{rk}} \quad$ : k karar verme birimi tarafindan üretilen r'inci çıtıtı,

$\mathrm{X}_{\mathrm{ik}} \quad$ : k karar verme birimi tarafindan kullanılan i'inci girdi,

$Y_{\mathrm{rj}} \quad$ : j'inci KVB tarafından üretilen r'inci çıktı

$\mathrm{X}_{\mathrm{ij}} \quad$ : j'inci Karar Verme Birimi 
olarak ifade edilir. VZA'da $n$ tane Karar Verme Birimi varsa, $n$ tane model oluşturulur ve her biri KVB'nin görece etkinliğinin ölçülebilmesi için $n$ tane en iyileme modelinin çözülmesi gerekir. Modellerin amaç fonksiyonu, $k$ karar verme birimi için toplam ağırlıklandırılmış çıktıların (sanal çıktıların), toplam ağırlıklandırılmış girdilere (sanal girdilere) oranının enbüyüklenmesidir. Modeldeki kısıtlar, her bir KVB için sanal çıktının sanal gidiye oranının 1'i geçmemesi gerektiğini ve en iyi amaç fonksiyonu değerinin $\left(\theta \theta_{k k}{ }^{*}\right)$ en fazla 1 olacağını gösterir. Yukarıda tanımlanan kesirli modelin doğrusal programlama çözüm yöntemleri ile çözülebilmesi için Charnes ve Cooper 1962'de $\sum_{i l=}^{m m} v v_{i i} X X_{i i k k}=1$ dönüşümünü yapmışlar ve modeli,

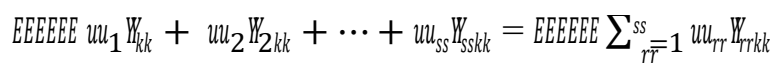

$$
\begin{aligned}
& v_{1} \cdot X X_{1 k k}+v_{2} X X_{2 k k}+\cdots+v_{m m} X X_{m m k}=1 \Rightarrow \underset{i i=1}{m m} v v_{i i} X X_{i k k}=1 \\
& u_{1} \cdot w_{1 i i}+u u_{2} W_{2 i i}+\cdots+u_{s s} W_{s i i} \leq w_{1} \cdot X X_{1 i i}+v_{2} X X_{2 i i}+\cdots+v_{m m} X X_{m m i i} \Rightarrow \underset{r r=1}{s s} u_{r r} W_{r i i}-\underset{i i=1}{m} v v_{i i} X X_{i i i i} \leq 0 \\
& u_{1}, u u_{2}, \ldots, u u_{s s} \geq 0 ; w_{1}, w_{2}, \ldots, v_{m m} \geq 0 \Rightarrow u u_{r T} \geq 0 ; w_{i i} \geq 0
\end{aligned}
$$

şeklinde ifade ederek DP modelini geliştirmişlerdir. Girdi yönelimli CCR modeli denilen bu model; ölçeğe göre sabit getiri varsayımı altında, görece toplam etkinliği ölçmekte ve kesirli modelle aynı en iyi çözümü vermektedir (Özden, 2008, s.170-171).

Modelde yer alan $v_{i}$ ve $u_{r}$ sanal ağırlıklardır. Sanal denmesinin nedeni, bu ağırlıkların gözlemlenmiş değil, türetilmiş olmalarından kaynaklanmaktadır. Sanal ağırlıklarla çarpılarak bulunan girdi ve çıktılara da bu nedenle sanal girdi ve çıktı denmektedir. Sanal ağırlıklar her bir karar verme birimi için ayrı ayrı belirlenmektedir (Yücel, 2017, s.22).

Tüm doğrusal programlama modelleri gibi VZA modelleri de primal ve dual olmak üzere iki farklı formda ifade edilebilir. Veri zarflama analizinde de dual model, primal modele göre en iyi çözüme ulaşmak için hem daha az matematiksel işlem gerektirdiğinden, hem de önemli yönetsel bilgiler sağladığından daha çok kullanılmaktadır. Dualite kuramı gereği primal model enbüyükleme (Enb) olduğu için bunun duali enküçükleme (Enk) olur ve primal modelin en iyi değeri $\left(Z Z_{k k}{ }^{*}\right)$ ile dual modelin en iyi değeri $\left(\theta_{k k}{ }^{*}\right)$ birbirine eşittir. Dolayısıyla dual model Enk olduğu $\theta \theta_{k k}{ }^{*}$ 'nın en iyi değeri 1'den büyük çıkamaz yani $0 \leq \theta \theta^{*}{ }_{k} \leq 1$ olur. Yukarıdaki modeldeki girdi yönelimli primal CCR modelinin, duali aşağıda yer almaktadır.

$$
\begin{aligned}
& ?_{i i=1}^{n n} \lambda \lambda_{i k k} X X_{i i i i} \leq \theta \theta_{k k} X X_{i i k k} \\
& 2_{i i=1}^{n n} \lambda \lambda_{i i k k} Y Y_{r r i i} \geq Y Y_{m k k} \\
& \lambda \lambda_{\text {iikk }} \geq 0
\end{aligned}
$$

Veri zarflama analizinde, bir karar verme biriminin, görece toplam etkin olduğunu söyleyebilmek için;

$$
\begin{aligned}
& \text { i. } \theta \theta_{k}^{*}=1 \\
& \text { ii. } S S_{i i}^{-}=0 \underset{r r}{v 000} S S_{r}^{+}=0
\end{aligned}
$$

koşullarının birlikte sağlanması gerekir.( $S_{i}^{-}$,DP modellerindeki eşitsizliklerin eşitlik haline dönüştürülmesi için fazla kullanılan girdilere ilişkin aylak değişlenleri ve $S S_{+}^{+}$, eksik üretilen çıktılara ilişkin aylak değişlenleri gösterir). Bir KVB'ye ilişkin amaç fonksiyonu değeri 1'den küçük $\left(\theta \theta_{k}^{*} \leq 1\right)$ ve/veya aylak değişkenler de sıfırdan farklı değerlere sahipse, $\left(S S_{i i} \neq 0\right.$ ve/veya 
$S S_{r r} \neq 0$ ), o KVB'nin görece toplam etkin olmadığ 1 sonucuna varılır. Literatürde yalnızca i'inci şartın sağlanması "zayıf" görece etkinlik; birinci şartın yanı sıra aylak değişken değerlerinin sıfıra eşit olduğunu gösteren ikinci şartın da sağlanması "güçlü" görece etkinlik olarak ifade edilir (Özden, 2008, s.172).

Yukarıda verilen modelin ikisinin birlikte gerçekleşip gerçekleşmediği ve görece toplam etkinliği araştırılan KVB'lerin olası girdi fazlalığı ve çıktı eksikliğinin belirlenmesi, aşağıdaki modelin iki aşamalı çözümünü gerektirir.

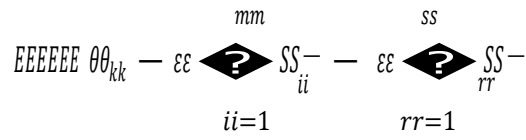

$$
\begin{aligned}
& S S_{i i}^{-}=\theta \theta_{k k} X X_{i i k k}-\gtrless_{i i=1}^{m n} X X_{i i i i} \lambda \lambda_{i i} \\
& S S_{r r}^{+}=\sum_{i i=1}^{m n} Y Y_{r r i l} \lambda_{i k k k}-Y Y_{r r k k} \\
& M_{i i k k}, S S_{i i}, S S_{r r} \geq 0 \text {; }
\end{aligned}
$$

Bu modelin çözümünün ilk aşamasında, bir önceki model çözülerek amaç fonksiyonunun en iyi değerị $(\theta \theta *$ * $)$ bulunur. İkinci aşamasında; birinci aşamada elde edilen çözümle elde edilen $\theta \theta^{*} k k$ degeri, yukarıdaki model yerine konularak dual degişkenlerin degerleri $\lambda \lambda^{*}, S S^{-*}$ ve $S S^{+*}$ bulunur (Özden, 2008, s.172).

Görece toplam etkinlikler, girdi yönelimli CCR modelinin yanı sıra çıktı yönelimli CCR modelleriyle de hesaplanabilir. Ancak bir KVB'nin görece toplam etkinliğinin yanlizca bir yönelime göre hesaplanması yeterlidir. Çünkü, girdi yönelimli CCR modelinden elde edilen görece toplam etkinlik değeri ile çıktı yönelimli CCR modelinden elde edilen görece toplam etkinlik değerleri birbirine eşittir. Ancak bu iki yönelime göre girdi ve çıktı değişkenlerinin potansiyel iyileştirme yüzdeleri birbirinden farklı çıkabilir (Özden, 2008, s.173).

\subsubsection{BCC Modelleri}

CCR modelleri ölçeğe göre sabit getiri varsayımı altında yani bütün KVB'lerin optimal ölçekte faaliyet gösterdikleri varsayımına dayanarak, görece toplam etkinliklerin hesaplanmasında kulanılmaktadır. Ancak gerçek hayatta ölçeğe göre değişen getiriye sahip olan sistemler de söz konusudur. Ölçeğe göre değişen getiri durumuna sahip sistemlerin etkinlikerini belirleyebilmek için, 1984 y1lında Banker, Charnes ve Cooper kendi isimlerinin baş harfleri ile anılan BCC modelini geliştirmişlerdir. Bunun için CCR modellerinin dualine konvekslik kısıtı denilen kısıtı eklemişlerdir. Bu kısıt sayesinde KVB'lerin ölçeğe göre getiri türleri de belirlenebilmektedir. Buna göre; bir KVB için hesaplanan $\lambda_{j}{ }^{\prime}$ lerin (ağırlıkların) toplamı birden büyük ise KVB ölçeğe göre azalan getiriye; birden küçük ise artan getiriye ve bire eşit ise sabit getiriye göre faaliyet gösteriyor anlamına gelmektedir (Özden, 2008, s.173-174). Konvekslik kısıtı şöyledir:

$$
?_{i i=1}^{n n} \lambda \lambda_{i i k k}=1
$$

Bir kümenin konveks olması, bu kümede yer alan, söz gelimi $\mathrm{X}$ ie Y'nin her türlü doğrusal bileşimlerinin yine bu kümede yer alması demektir. Bu basit ama aydınlatıcı fikir, etkin sınırın gözlem noktalarını daha sıkı zarflamasına neden olmaktadır. CCR modelde $\lambda$ yoğunluk vektörünün öğelerine ilişkin tek kısıt sıfirdan büyük veya eşit olmaları yönündedir. Toplamlarına dair bir kısıt yoktur. Bu durum CCR etkin sınırının BCC etkin sınırına göre daha kuzeybatıda yer almasına ve daha geniş bir bölgeyi içine almasına neden olmaktadır. BCC modelin etkin sınırı $\mathrm{CCR}$ modelinkine göre karar birimlerine daha yakın bir konumdadır. $\mathrm{Bu}$ nedenle, bir karar 
biriminin CCR etkin olması BCC etkin olmasından daha zordur. CCR modelin etkin sinırı orjinden geçmek zorundadır, fakat BCC'de böyle bir kısıtlama bulunmamaktadır (Yücel, 2017, s.28).

Girdi yönelimli BCC modelinin primal ve dual biçimleri aşağıda yer almaktadır.

\section{Primal BCC}

Enk $\theta \theta_{k k}$

$$
\begin{gathered}
\theta \theta_{k k} X X_{i i k k}-\gtrless_{i i=1}^{m n} \lambda \lambda_{i i k k} X X_{i i i i} \geq 0 \\
?_{i i=1}^{m n} \lambda \lambda_{i k k} Y Y_{r r i i} \geq Y Y_{\text {rrkk }} \\
\lambda \lambda_{i i k=1}^{m} \lambda \lambda_{i i k k}=1 \\
\lambda \lambda_{i i k} \geq 1
\end{gathered}
$$

\section{Dual BCC}

$$
\begin{gathered}
\text { EEEEEE } \overbrace{r r=1}^{s s} u u_{r r} Y Y_{r r k k}-u u_{k k} \\
u u_{r r}, v v_{i i} \geq \varepsilon \varepsilon \geq 0, u u_{k k}
\end{gathered}
$$

\subsubsection{VZA ile Firma Değerlemesi ve İlişskili Literatür}

Klasik değerleme metotlarının yanı sıra, değerleme uzmanlarının kullanabileceği yeni değerleme metotlarının geliştirilmesinin önemli olduğu düşünüldüğünden, bu çalışma hazırlanmış olup, veri zarflama analizi de, firma değerlemesinde kullanılabilecek alternatif bir araç olarak karşımıza çıkmaktadır.

Dünya literatüründe, veri zarflama analizinin firma değerlemesinde kullanımına ilişkin kısıtlı sayıda çalışma bulunduğu görülmekle birlikte, Türkçe literatürde bu yöntemin değerlemede kullanımına ilişkin bir çalışmaya ise rastlanmamıştır. Esas olarak, çalışmanın önemi de buradan kaynaklanmakta ve yapılacak bu çalışma ile Türkiye' de henüz kullanılmamış bir yöntem ile firma değerlemesi yapılmış olacak ve bu yapılırken de yöntemin geliştirilebilecek yönleri araştırılacaktır.

Literatürde, veri zarflama analizi ile firma değerlemesi konusunu doğrudan işleyen çalışmaları ve bu çalışmalara ilişkin kısa bilgiler aşağıdaki gibi sıralanabilir. Yukarıda da belirtildiği üzere, bu çalışmaların tamamı Türkiye dışında yapılmıştır.

Yapılan bu çalışmalardan ilkinin amacı, şirketlerin değerini doğru bir şekilde saptamak ve bu kapsamda Veri Zarflama Analizi'nin yeteneklerinden faydalanan bir metodoloji geliştirmektir (Simak, 2000). Çalışmada, üretim sektöründe faaliyet gösteren 51 adet halka açık firmanın 1997 
yılına ait girdi ve çıktı verileri ile piyasa değerleri kullanılmış ve girdiye yönelik BCC VZA analizi yapılmıştır. Çalışmada girdi olarak toplam varlıklar ve toplam yükümlülükler alınmış, çıktı olarak ise net kar, işletme sermayesi ve dağıtılmamış karlar alınmıştır. Çalışmada, VZA'nın verimsiz olduğu tespit edilen firmaların kendilerini örnek aldıkları firmanın tespit edilmesi özelliğinden yola çıkılmıştır. Bu kapsamda, firmaların benzerliklerinin ortaya konmasında, firmaların VZA sonucunda bulunan lamda değerleri arasındaki yakınlık ve ayrıca bu firmaların VZA sonucu aldıkları verimlilik puanları dikkate alınmıştır. Lamda, etkin olmayan birimlerin sanal etkin sınır oluşturan etkin birimlere hangi oranda benzemesi gerektiğini göstermektedir. Lamda değerleri arasındaki yakınlık ise fark göstergesi adı verilen aşağıdaki formül yardımıyla hesaplanmıştır. Fark göstergesi ne kadar küçükse, firmalar birbirine o kadar benzerdir.

$$
\delta \delta_{i i i i}=\boldsymbol{P}\left(\lambda_{i i k k}-\lambda \lambda_{i k k}\right)^{2}
$$

Çalışmanın sonucunda, tüm piyasa tabanlı değerleme metodolojilerinde olduğu gibi VZA ile değerlemenin daha fazla data seti kullanıldığında daha güvenilir olduğu sonucuna varılmıştır. Veri zarflama ile değerleme uygulamasında aynı sektörden ve coğrafi konumdaki şirketleri içeren yeterince büyük bir halka açık şirket veri tabanının kullanılması gerektiği de vurgulanmıştır.

Konuya ilişkin olarak yapılan başka bir çalışmada, referans alınabilecek karşılaştırılabilir firmaları araştırmak ve şirketlerin piyasa değerlerini tahmin etmek için Veri Zarflama Analizi kullanılmıştır (Anadol, 2000). Çalışmada, üretim sektöründe faaliyet gösteren ve hisseleri halka açık şirketlerin 1997 yılı verileri kullanılmıştır. Analizde toplam varlıklar, toplam yükümlülükler, özkaynak girdi olarak kullanılmış, net satışlar, kar ve nakit akışları ise çıktı olarak seçilmiştir. Yapılan analiz sonucunda, verimsiz olduğu tespit edilen şirketlerin \%70'i için pazar değeri aralıkları doğru bir şekilde sınıflandırılmıştır. Verimli akranlarına (peers) göre göreceli olarak verimsiz şirketler için üst sınır öngörüsünde bulunulmuştur. Bunların \% 75'inin tespit edilen üst sınırın altında olduğu görülmüştür. Sonuç olarak, yapılan çalışmadan tespit edilen değer aralıklarının bazılarının oldukça geniş olduğu görülmesine rağmen, yöntemin pazar değerlerini sınıflandırmak için hala nispeten iyi bir iş çıkardığ 1 sonucuna varılmıştır.

VZA ile yapılan bir başka değerleme çalışmasında, analiz için toplam varlıklar ve toplam yükümlülükler girdi olarak, özkaynak, net kar, net satışlar ile nakit akışlarını çıktı olarak belirlenmiştir. Model olarak, aylak değişkenleri dikkate alan, girdi ve çıktı yönelimsiz SBM (slacks-based measure) modelininin ölçeğe göre değişken getiri (VRS) yaklaşımını kullanmışlardır. Çalışmada, 6000'den fazla Amerikan şirketinden rastgele seçilen 500 şirketin 2013 yılı verileri analiz edilmiştir. Çalışmanın doğrulanma aşamasındaki sonuçlara göre, etkin olmayan firmaların \%36,93'ünün gerçek değerinin, analiz sonucunda tespit edilen değer aralığı içerisinde yer aldığı görülmüştür. Yine verimsiz firmaların \%66,2'sinin gerçek değerlerinin VZA sonucunda bulunan maksimum değerin altında olduğu tespit edilmiştir. Sonuç olarak VZA ile değerleme modelinin, uygun pazar aralıklarını tahmin ederken önemli ölçüde rahatlık sağladığına dikkate çekilmiştir (Anadol ve Diğ, 2014).

\section{Uygulama}

VZA kullanılarak yapılan çalışmalarda karar verme birimlerinin, VZA modelinin ve girdi çıktı veri setinin seçimi son derece önemlidir. Aşağıdaki başlıklarda bunların seçimine ilişkin neden ve sonuçlar ele alınmış ve nihayetinde de yapılan uygulamanın sonuçları aktarılmıştır.

\section{1. Karar Verici Birimlerin Seçilmesi}

VZA'da ilk aşama, yapılacak olan çalışmanın amacına uygun olarak KVB'lerin tespit edilmesidir. Seçilen karar birimlerinin etkinliklerinin sağlıklı bir şekilde ölçülebilmesi için gerekli birim sayısının girdi ve çıktı sayısının en az üç katı olması gerektiğini savunanlar bulunmaktadır. Diğer 
taraftan, yapılan çalışmalardan elde edilen deneyimler doğrultusunda bu sayının en az yirmi olması gerektiğini savunanlar da bulunmaktadır. Uygulamada en çok karşılaşılan durum ise, seçilen karar birimi sayısının girdi ve çıktı sayısının en az iki katı olması gerektiğidir (Kutlar ve Bakırc1, 2018, s.182-183).

Daha sistematik bir yaklaşımla, çalışmanın güvenilirliğinin yüksek olabilmesi bakımından, KVB sayısının belirlenmesinde genel kabul gören kısıt; analize en az $\mathrm{m}+\mathrm{p}+1$ adet KVB alınması gerektiğidir. Burada $\mathrm{m}$ seçilen girdi sayısını gösterirken, $\mathrm{p}$ çıktı sayısını göstermektedir (A $\breve{g}$, 2019, s.2662).

İşbu çalışma kapsamına BIST’te faaliyet göstermekte olan gıda sektörü firmaları dahil edilmiştir. Çalışmada kullanılan veriler KVB'lerin 2019 yılına ait bilanço, gelir tabloları ile faaliyet raporlarından temin edilmiştir. Verilerin elde edilebilirliği ve güvenilirliği açısından KVB'lerde ulaşılamayan (BIST Gıda Sektörü Firmaları) veya doğruluğundan kuşku duyulan herhangi bir değer bulunmamaktadır.

Çalışma yapılırken verileri mevcut en yakın tarih olan 2020 yılı verilerinin seçilmemesinin nedeni COVID 19 salgınının etkilerinin en yoğun olarak görüldügü ve dolayısıyla da firmaların mali verilerinin de bundan etkilenmiş olduğu yılın 2020 yılı olmasıdır. 2020 yılının istatistiki olarak aykırı bir yıl olduğu kabul edilmiş ve 2020 yılı yerine 2019 yılı esas alınarak analiz gerçekleştirilmiştir.

Diğer taraftan, KVB sayısının belirlenmesinde genel kabul gören $m+n+1$ kısıtı da bu analiz kapsamında karşılanmaktadır. Buna göre analize en az $3+2+1=6$ adet KVB alınması gerekmektedir. Çalışma kapsamında 25 adet KVB yer almakta olup bu kısıt sağlanmaktadır.

\subsection{VZA'ya Dahil Edilecek Girdi ve Çıktıların Seçimi}

VZA'da girdi ve çıktılar arasında fonksiyonel bir bağ kurulması söz konusu olmadığı için yöntemi uygulayacaklara geniş bir çalışma alanı açmasının yanı sıra girdi ve çıktı değişkenlerini dikkatli bir şekilde seçme yükümlülügünü de beraberinde getirmektedir. Yanlış değişkenlerin seçilmesi durumunda model doğru bir sonuç vermeyecektir (Çam ve Sulak, 2019, s.39).

Etkinlik kavramının girdi-çıtı değişkenlerine yüksek oranda bağımlı bir kavram olması nedeniyle, aynı karar birimlerinin farklı girdi-çıktılar ile analiz yapıldığında dahi tam tersi sonuçların elde edilmesi mümkündür (Yakut ve Kuru, 2019, s.33).

VZA için girdi-çıktı değişkenlerinin aynı birimlere sahip olmaması gerekmemektedir. Örneğin, değişkenlerin birisi personel sayısını temsilen kişi sayısı olabilirken, diğeri toplam giderlerin karşıllı̆ 1 olarak para birimi olabilir. Yine aynı analizde örneğin bir hammadde girdisi varsa bunun birimi kilogram olarak alınabilir (Yakut ve Kuru, 2019, s.33).

Literatür taraması neticesinde ve veri zarflama ile yapılan değerleme çalışmalarında kullanılan girdi ve çıktı değerlerinin incelenmesi neticesinde bu çalışma kapsamında yapılacak olan veri zarflama analizinde girdi olarak personel sayısı, toplam varlıklar ile toplam yükümlülüklerin, çıktı olarak ise net satışlar ile net karın alınmasına karar verilmiştir. Analizde girdi ve çıktıların aynı birime sahip olmaları gerekmediğinden, girdi olarak alınan çalışan sayısının biriminin kişi sayısı olması, diğer girdi ve çıtıların birimlerinin ise milyon TL olması herhangi bir sorun teşkil etmemektedir. Yukarıda da ifade edildiği üzere bu durum VZA'nın en büyük avantajlarındandır.

Etkinlik analizinde kullanılan bir girdi değişkeni ile çıktıların tamamı arasındaki korelasyonun düşük olması durumunda, söz konusu girdinin araştırmada kullanılması anlamlı değildir. $\mathrm{Bu}$ çalışma kapsamındaki girdi ve çıktı değişkenleri arasındaki korelasyon analizinden 0,923-0,996 aralığında korelasyon katsayıları elde edilmiştir. Bu sonuçlar dikkate alındığında, girdi ve çıktılar arasında oldukça yüksek düzeyde bir korelasyon bulunmakta olduğundan çalışmada girdi-çıktı korelasyonuna ilişskin gerek koşul da sağlanmış olmaktadır. 
Diğer taraftan, girdilerin kendi içerisinde, çıktıların da kendi içerisinde yüksek korelasyona sahip olmaları, modelde atanan ağırlıkların değişkenler arasında taşınmasına neden olabilmektedir. $\mathrm{Bu}$ nedenle, aralarında yüksek korelasyon bulunan değiş̧kenlerin VZA modeline eklenmesi genellikle önerilmemektedir. Bununla birlikte, korelasyonlu değişkenlerden birinin VZA modelinde dikkate alınmaması da etkinlik hesaplamalarında önemli farklılıklar yaratabilir (Esenlik Telatar, 2020, s.768-778). Bu çalışma kapsamına dahil edilen girdi ve çıtılar da bu nitelikte olup, aralarındaki korelasyona rağmen, bu çalışmada, bu faktörlerin de girdi olarak dikkate alınması uygun görülmüştür. Diğer taraftan, VZA ile değerleme alanında ve ayrıca gelir tablosu ve bilanço verilerini kullanarak yapılan VZA çalışmalarında, bu çalışma kapsamında alınan girdi ve çıktıların analize dahil edildiği görülmüştür.

\subsection{Model Seçimi}

Veri zarflama analizinin, en önemli adımlarından birisi de, kullanılacak olan modelin seçimidir. Çalışmalarda, farklı amaçlara uygun olarak yapılan analizleri kolaylaştırmak için farklı VZA modelleri kullanılabilmektedir. Bunlar girdi ve çıktı yönelimli yaklaşımlar olabileceği gibi, CCR ve BCC gibi yaklaşımlarla da kombine edilebilmektedir.

Girdi ve çıktılar arasında oransal bir artış veya azalış var ise ölçeğe göre sabit getiri (CCR), aksi takdirde ölçeğe göre değişken getiri (BCC) yaklaşımı kullanılmaktadır (Çam ve Sulak, 2019, s.41). Bu çalışma kapsamında kurulan modelde de girdi ve çıktılar arasında oransal bir artış olmadığı ön görüldüğünden, ölçeğe göre değişken getiri yaklaşımı seçilmiştir.

Yine modelin yöneliminin belirlenmesi de oldukça önemlidir. Amaç belli bir girdi ile maksimum çıktı üretmek mi, yoksa belirli bir çıktıyı en az girdi ile üretmek mi olup, bu konu açıça ortaya konulmalıdır (Yücel, 2017, s.35). Şayet girdiler üzerinde hakimiyet daha fazla ise girdi odaklı, çıtılar üzerinde daha fazla hakimiyet gücüne sahipse çıktı odaklı VZA modellerinin uygulanması doğru olacaktır. Aksi takdirde, elde edilen sonuçların, karar verme ve yeni politikaların üretilmesi aşamasında bir katkısı olmayacaktır (Çam ve Sulak, 2019, s.41). Bu çalışma kapsamındaki uygulamada da girdi odaklı VZA modeli tercih edilmiş olup, bunun nedeni çıktılar üzerindeki kontrolün girdiler üzerindeki kontrolden daha fazla olduğu bir girdi çıktı setinin seçilmiş olmasidir.

Modelin seçiminde bir diğer önemli konu, girdi ve çıktı verilerinden negatif olanlarının bulunup bulunmadığıdır. Negatif verilerin kullanılabildiği modeller mevcut olup, çalışma kapsamında kullanılan net kar verisinin negatif değerlere sahip olduğu birimlerin bulunması nedeniyle, analize bu modellerle devam etmek gerekmektedir. Negatif değer alan çıtıları pozitif yapabilmek için bu verilerin tamamına (pozitif ve negatif verilerin tamamına) belirli bir sayının eklenmesine imkân veren ve analiz sonuçlarında herhangi bir bozulmaya sebebiyet vermeyen girdiye yönelik radyal VRS (BCC) modeli bu çalışma kapsamında seçilmiştir (Çam ve Sulak, 2019, s.41).

\subsection{Bulgular}

\subsubsection{VZA Analiz ve Değerleme Bulguları}

Veri Zarflama Analizinin yapılabilmesi bakımından, konuya ilişkin internet sitelerinden ilgili software programları edinilmiştir. Efficiency Masurement System adlı programın, bu çalışma kapsamındaki ihtiyaçları giderebileceği anlaşılmıştır. Bu program yardımıyla gerçekleştirilen analiz sonucunda verimlilik skorları ile verimsiz firmalar için bulunan emsal firmalar ve lamda değerleri bulunmuştur.

VZA sonucunda, 25 firmadan 13'ünün verimlilik skoru \%100 (yani verimli) bulunmuştur. Kalan 12 firma ise \%30,3 ve \%94,8 oranlarında değişen verimlilik skorlarına sahiptir. 
VZA sonuçlarının alınmasının akabinde, kendilerini aynı verimli firmaları örnek olarak alan üç verimsiz firmanın değer aralıkları ve maksimum değerlerinin hesaplaması yapılmıştır. Öncelikle lamda değerleri baz alınarak fark göstergesi hesaplanmıştır. Yukarıda da belirtildiği üzere lamda değerleri arasındaki yakınlık fark göstergesi adı verilen aşağıdaki formül yardımıyla hesaplanmaktadır. Fark göstergesi ne kadar küçükse, firmalar birbirine o kadar benzerdir. Yine firmaların benzer olup olmadığına karar verilirken, verimlilik skorlarının da birbirlerine yakın olup olmadığ 1 dikkate alınmıştır.

Aşağıda örnek olarak, çalışmaya dahil edilen firmalardan birisi olan AVOD firması için değer aralı̆̆1 ve maksimum değer hesaplamaya ilişkin açıklamalar tablolar halinde verilecek olup, AVOD ile aynı firmaları kendisine emsal olarak seçen diğer iki firma olan Frigo Pak ve Kerevitaş firmalarının değer analizlerinin sonuçları ise özet olarak verilmiştir.

\subsubsection{AVOD Firması İçin Değer Aralığı Hesaplaması}

Aşağıda VZA sonucunda verimsiz bulunan AVOD firması için fark göstergesi hesaplamasına ilişskin tablo (Tablo 1) yer almaktadır.

Tablo 1. AVOD Fark Göstergesi, Verimlilik Skoru ve Piyasa Dĕger Tablosu

\begin{tabular}{llll}
\hline Firma Adı & Fark Göstergesi & Verimlilik Skoru & $\begin{array}{l}\text { Piyasa Değeri } \\
\text { (Milyon TL) }\end{array}$ \\
\hline AVOD & 0,0000 & $52,20 \%$ & 167 \\
DARDANEL & 1,7336 & $100,00 \%$ & 202 \\
FRİGO-PAK & 0,0022 & $94,80 \%$ & 78 \\
KEREVİTAŞ & 1,1635 & $57,80 \%$ & 2.158 \\
TAZE KURU & 0,0136 & $100,00 \%$ & 7 \\
TÜRK TUBORG & 1,7336 & $100,00 \%$ & 3.838 \\
ULUSOY UN & 1,7736 & $100,00 \%$ & 323 \\
\hline
\end{tabular}

Buna göre, AVOD ile fark göstergesi en düşük olan yani AVOD'a en yakın olan firmalar FrigoPak $(0,0022)$ ile Taze Kuru $(0,0136)$ firmalarıdır. Taze Kuru firmasının verimlilik skoru \%100 olduğundan AVOD firması $(\% 52,2)$ ile büyük farkl1lık göstermekte olup bu firma (Taze Kuru) karşılaştırma dışı bırakılmalıdır. Yine Frigo-Pak firmasının da verimlilik skorunun \%94,8 olması nedeniyle, her ne kadar fark göstergesi en yakın iki firmadan birisi olsa da değerlendirme kapsamına alınmamalıdır. Bu durum, fark göstergeleri ve verimlilik skorları birlikte değerlendirildiğinde AVOD firmasının, bu yöntemle değer aralığının hesaplanamayacağını göstermektedir.

Diğer taraftan, AVOD firmasının maksimum değerinin bulunabilmesi amaciyla, AVOD'un kendisini örnek aldığı etkin firmaların piyasa değerleri ile AVOD'un bu firmalar ile arasındaki lamda değerleri çarpılır ve toplamı alınması gerekmektedir. Bulunan bu değer AVOD firması için üst değer olarak değerlendirilir. Buna ilişkin hesaplama tablosu aşağıda yer almaktadır. 
Aypek, N. - Üzgün, Y. O. (2022). 9/1, 1-19

Tablo 2. AVOD Maksimum Değer Hesaplama Tablosu

\begin{tabular}{|c|c|c|c|c|c|}
\hline & Dardanel & $\begin{array}{l}\text { Taze } \\
\text { Kuru }\end{array}$ & $\begin{array}{l}\text { Türk } \\
\text { Tuborg }\end{array}$ & $\begin{array}{l}\text { Ulusoy } \\
\text { Un }\end{array}$ & $\begin{array}{l}\text { AVOD } \\
\text { Maksimum }\end{array}$ \\
\hline AVOD Lamda Değeri & 0,04 & 0,90 & 0,04 & 0,02 & Değeri \\
\hline $\begin{array}{l}\text { Verimli Firmaların Piyasa } \\
\text { Değeri (Milyon TL) }\end{array}$ & 202 & 7 & 3838 & 323 & $\begin{array}{l}\text { (Milyon } \\
\text { TL) }\end{array}$ \\
\hline $\begin{array}{l}\text { Lamda Çarpı Verimli Firma } \\
\text { Değeri }\end{array}$ & 8,08 & 6,3 & 153,52 & 6,46 & 174,36 \\
\hline
\end{tabular}

Söz konusu yöntem aracılığılla AVOD'un maksimum piyasa değeri 174,36 milyon TL olarak hesaplanmaktadır. AVOD'un gerçek piyasa değerinin 167 milyon TL olduğu dikkate alındığında gerçek değerin maksimum değerin altında kaldığı görülmektedir. Bu durum, bu alt analizin başarılı sonuçlar verdiğini göstermektedir.

\subsubsection{Frigo Pak ve Kerevitaş Firmaları İçin Değer Analizi}

AVOD firması her ne kadar fark göstergesi Frigo Pak'a en yakın firma olsa da, verimlilik skoru Frigo Pak firmasından oldukça farklı olduğundan, bu iki firmanın değer karşılaştırması yapılamayacaktır. Bunun dışında diğer en yakın iki fark göstergesi değeri Taze Kuru $(0,0054)$ ve Kerevitaş'tır $(1,2649)$. Taze Kuru firmasının verimlilik skoru \%100 olduğundan, Frigo Pak'a $(\% 94,8)$ yakın olması nedeniyle değer karşılaştırmasında dikkate alınabilir bulunmuştur. Kerevitaş'ın verimlilik skorunun \%57,8 olması nedeniyle karşılaştırmaya dahil edilmemiştir. Bunlar dışında, verimlilik değeri ile firma değeri en yakın olan firma olarak Dardanel firması bulunmuştur. Bu durumda, hem verimlilik puanı hem de firma değeri bakımından en yakın olan iki firmanın gerçek değeri Frigo Pak'ın değer aralığını verecektir. Taze Kuru (7 Milyon TL) ve Dardanel (202 milyon TL) firmalarının değer aralığı olan 7-202 Milyon TL Frigo Pak'ın değer aralığı olarak alınmalıdır. Gerçekten de Frigo Pak'ın gerçek değeri 78 milyon TL olup bu iki değer aralığı içerisinde yer almaktadır. Bu durum, daha önce AVOD için başarısız bulunan alt analizin Frigo Pak firması için denendiğinde başarılı bulunduğunu göstermektedir.

Söz konusu yöntem aracılığıyla Frigo Pak'ın maksimum piyasa değeri 127,78 milyon TL olarak hesaplanmaktadır. Frigo Pak'ın gerçek piyasa değerinin 78 milyon TL olduğu dikkate alındığında gerçek değerin maksimum değerin altında kaldığı görülmektedir. Bu durum, bu alt analizin başarılı sonuçlar verdiğini göstermektedir.

Kerevitaş firmasının değer analizine bakıldığında, Kerevitaş ile fark göstergesi en düşük olan iki firma Ulusoy Un $(0,3023)$ ve Türk Tuborg $(0,7823)$ firmalarıdır. Ancak her iki firmanın da verimlilik skorunun Kerevitaş'tan oldukça farklı olması nedeniyle (her ikisi de \%100) değer aralığı analizine dahil edilmemişlerdir. Bunlar dışında AVOD firmasının fark göstergesi Kerevitaş'a üçüncü yakın firmadır ancak bu firmanın da piyasa değeri 167 milyon TL olup, Kerevitaş' in piyasa değerinden oldukça farklı olduğundan analize dahil edilememiş̧tir. Sonuç olarak Kerevitaş firması için VZA ile bulunan fark göstergelerinden bir değer aralığına ulaşılamamıştır.

Kerevitaş'ın olması gereken maksimum değeri VZA sonucunda 1.468 milyon TL olarak hesaplanmıştır. Kerevitaş'ın gerçek değeri 2.158 milyon TL olup, bu durum, VZA ile elde edilen maksimum değerin firma için en yüksek sınır olduğu varsayımıyla, firmanın fazla değerlendiğine ilişkin bir işaret olabilir. 


\section{Sonuç ve Tartışma}

Birleşme ve satın almaların küresel ölçekte artması ve halka açılan şirket sayısının artmasıyla birlikte değerleme metodolojileri giderek artış göstermektedir. Bir işletmeyi satarken, mal varlığ anlaşmazlıklarının çözümünde veya şirket birleşmeleri için değer tespiti faaliyetleri, herhangi bir işletmenin önemli bir parçası haline gelmiştir.

Literatürde kabul görmüş ve yaygın olarak kullanılan değerleme yöntemleri "muhasebe esaslı değerleme yaklaşımı", "piyasa esaslı değerleme yaklaşımı", "nakit akış esaslı değerleme yaklaşımı" ve "diğer değerleme yöntemleri" olarak sınıflandırılmaktadır.

VZA ile firma değerlemesi esas olarak piyasa esaslı bir değerleme türüdür. Bu yöntemde diğer piyasa esaslı değerleme yöntemlerinde olduğu gibi birbirine benzeyen firmalar tespit edilmekte ve değeri aranan firmanın değeri emsal alınan firmanın değerine göre tespit edilmektedir.

VZA ile değerlemede öncelikle VZA ile firmalar birbirleriyle karşılaştırılarak verimli ve verimsiz firmalar belirlenmekte, verimsiz firmaların hangi verimli firmaları kendilerine örnek aldıkları tespit edilmekte, akabinde aynı firmaları kendilerine örnek alan verimsiz firmalar ile birlikte örnek alınan verimli firmalardan bir alt küme oluşturulmaktadır. Bu alt küme içerisindeki firmaların, lamda değerleri, fark göstergeleri, piyasa değerleri gibi değişkenler yardımıyla birbirine en çok benzeyen firmalar bulunabilmekte, en çok benzeyen firmalar yardımıyla da değeri aranan firma için değer aralıkları ve ayrıca örnek alınan verimli firmaların piyasa değerleri kullanılarak üst sınır değeri hesaplaması yapılabilmektedir.

VZA tabanlı değerleme, aynı modelde birden fazla girdi ve çıktının kullanılmasına izin vermektedir. Örneğin bu çalışmada, çalışan sayısı, toplam varlık ve toplam yükümlülükler girdi olarak ele alınırken, net satışlar ve net kar çıktı faktörü olarak modele dahil edilmiştir. Çoklu girdi ve çıktının kullanımına imkan vermesi, VZA ile firma değerlemesini, diğer piyasa esaslı değerleme yaklaşımlarından avantajlı kılmaktadır.

Çalışma kapsamında BIST Gıda Sektöründe yer alan 25 firma için uygulanan değerleme uygulamasından, karşılaştırılabilir firma sayısının düşük sayıda bulunmuş olması nedeniyle tatmin edici firma değeri aralıkları bulunamamıştır. Çalışmada, VZA için yeter sayıda karar verme birimi analize dahil edilmiş olmasına rağmen, ya firmalar için karşılaştırılabilir firma bulunamamış ya da bulunan firmaların değer aralıkları analiz edilen firmanın gerçek değerini kapsamamıştır.

Diğer taraftan, üç firma için maksimum değer hesaplamasında, iki firmanın gerçek değerinin, VZA ile bulunan maksimum değerin altında olduğu görülmüş̧ür. Bu durum, VZA ile değer hesaplamasının maksimum değerin bulunmasında az sayıda veri ile dahi başarılı olduğunu göstermekte ve modelin kullanılabilirliği noktasında umut verici bir gelişme olarak değerlendirilmektedir.

Buradan çıkan sonuç, VZA ile değerleme çalışmasının çok daha yüksek sayıda veri seti ile birlikte yapılması gerektiğidir. VZA ile değerlemede firma sayısı arttıkça daha fazla akran firma bulunabilecek ve daha hassas değer aralıkları tespit edilebilecektir.

\section{Kaynakça}

Ağ, A. (2019). BIST’te İşlem Gören Sigorta Şirketlerinin Veri Zarflama Analizi Yöntemi İle Finansal Performanslarinin Analizi, Business And Management Studies An International Journal, 7(5), 2656-2668.

Anadol, B. (2000). Valuing Private Companies: A DEA Approach, Yüksek Lisans Tezi, University of Toronto, Toronto, Canada. 
Anadol, B., Paradi, J., Simak, P., Yang, X. (2014). Valuing Private Companies: A DEA Approach, International Journal of Business and Management, 9(12),16-27.

Anderson, P. L. (2012). The Economics of Business Valuation: Towards a Value Functional Approach., Stanford Economics and Finance, Stanford, California.

Chend G., Zervopoulos, P. (2013). A Variant Of Radial Measure Capable Of Dealing With Negative Inputs and Outputs In Data Envelopment Analysis, European Journal of Operational Research, 225(1),100-105.

Copeland, T.E. (1994). Why value value? McKinsey Quarterly, 4, s.97-109.

Çam A., Sulak H. (2019). Veri Zarflama Analizi ile İsgǚü Piyasası Bölgesel Etkinlik Analizi, Bursa: Ekin Yayınevi.

Damodaran, A., Valuation Approaches and Metrics: A Survey of the Theory and Evidence, http://pages.stern.nyu.edu/ adamodar

Demirci, A. (2018). Teori ve Uygulamalarla Veri Zarflama Analizi. Ankara: Gazi Kitabevi.

Ercan, M.K., Öztürk M.B., Demirgüneş, K. (2003). Değere Dayalı Yönetim ve Entelektüel Sermaye. Ankara: Gazi Kitabevi.

Ercan, M.K., Öztürk, M.B., Küçükkaplan, İ., Başçı, S., Demirgüneş, K. (2003). Firma Değerlemesi "Banka Uygulaması. İstanbul: Literatür Yayınları.

Esenlik Telatar, D., Sarı, K. (2020). Ağız ve Diş Sağlığı Hizmeti Sunan Tesislerin Etkinlik Ölçümü İçin Bir Veri Zarflama Analizi Modeli: İstanbul Örneği, Pamukkale Üniversitesi Mühendislik Bilimleri Dergisi, 26(4), 768-778.

International Valuation Standards Council (2019). International Valuation Standards (IVS). https://www.rics.org/globalassets/rics-website/media/upholding-professionalstandards/sector-standards/valuation/international-valuation-standards-rics2.pdf

Kutlar, A., Babacan, A. (2008). Türkiye'deki Kamu Üniversitelerinde CCR Etkinliği-Ölçek Etkinliği Analizi: DEA Tekniği Uygulaması, Kocaeli Üniversitesi Sosyal Bilimler Dergisi, (15), 148-172.

Kutlar, A., Bakırcı F. (2018). Veri Zarflama Anlizi (Data Envelopment Analysis DEA) Teori ve Uygulama DEA-Solver Win4DEAP MALMQUIST Endeksi. Ankara: Orion Kitabevi.

Özçelik, F., Avcı Öztürk, B. (2019). Girdi Olarak Maliyetlere Yönelik Veri Zarflama Analizi Modelleri İle Göreli Etkinlik Analizi. İşletme Araştırmaları Dergisi, 11(2), 1011-1028.

Özdemir, L., Göktaş, A. (2019). Borsa İstanbul'da Yer Alan Petrol İşletmelerinin Etkinliklerinin Ölçülmesi: Veri Zarflama Analizi. Afyon Kocatepe Üniversitesi İktisadi ve İdari Bilimler Dergisi, 21(2), 140-147.

Özden, Ü. (2008). Veri Zarflama Analizi (VZA) ile Türkiye'deki Vakıf Üniversitelerinin Etkinliğinin Ölçülmesi. İstanbul Üniversitesi İşletme Fakültesi Dergisi, 37(2), 167 - 185.

Öztürk, H. (2009). Şirket Değerlemesinin Esaslart-Teorik ve Pratik Yaklaşımlar. İstanbul: Türkmen Kitabevi.

Simak, P.C. (2000). Inverse and Negative DEA And Their Application To Credit Risk Evaluation, Doktora Tezi, University of Toronto, Toronto, Canada.

Sipahi B., Yanık, S., Aytürk, Y. (2016). Şirket Değerleme Yaklaşımları İlkeler - Yöntemler Uygulamalar. Ankara: Seçkin Yayıncılık.

Tarım, A. (2001). Veri Zarflama Analizi Matematiksel Programlama Tabanlı Göreli Etkinlik Ölçüm Yaklaşımı, https://armagan.github.io/SAT/DeaBook.pdf 
Tümer, N. (2008). Veri Zarflama Analizi Kullanarak Türkiye'deki Otel Sektöründe Etkinlik Ölçümü. Doktora Tezi, Marmara Üniversitesi, Avrupa Birliği Enstitüsü, İstanbul.

Ulucan, A. (2002). İSO 500 Şirketlerinin Etkinliklerinin Ölçülmesinde Veri Zarflama Analizi: Farklı Girdi Çıktı Bileşenleri ve Ölçeğe Göre Getiri Yaklaşımları ile Değerlendirmeler. Ankara Üniversitesi SBF Dergisi, 57(02), 185-202.

Yakut E., Kuru, Ö. (2019). Türkiye'deki Mevduat Bankalarının Finansal Etkinliklerinin Veri Zarflama (VZA) ile Ölçülmesi C5.0 ve CART Algoritması ile Karar A ğaçlarının Oluşturulmast:2009-2017 Dönemi. Ankara: Gazi Kitabevi.

Yücel İşbilen, L. (2017). Veri Zarflama Analizi, Frontier Analyts ve WinDeap ile Portföy Etkinlik Ölçümü Örneği ve Çeşitli Uygulamalar. İstanbul: DER Yayınları. 
BIST Gıda Sektörü 2019 Firmaları VZA Girdi, Çıktı ve Gerçek Piyasa Değeri Tablosu

\begin{tabular}{|c|c|c|c|c|c|c|c|}
\hline \multirow{3}{*}{ Sura } & \multirow{3}{*}{ Firma Adı } & \multicolumn{3}{|l|}{ Girdiler } & \multicolumn{2}{|l|}{ Çıktılar } & \multirow{3}{*}{$\begin{array}{l}\text { Piyasa } \\
\text { Değeri } \\
\text { (Milyon } \\
\text { TL) }\end{array}$} \\
\hline & & \multirow{2}{*}{\begin{tabular}{|l|}
$\begin{array}{l}\text { Çalışan } \\
\text { Sayısı }\end{array}$ \\
(Kişi) \\
\end{tabular}} & \multirow{2}{*}{\begin{tabular}{|l} 
Toplam \\
Varlıklar \\
(Milyon \\
TL)
\end{tabular}} & \multirow{2}{*}{$\begin{array}{l}\text { Toplam } \\
\text { Yükümlülükler } \\
\text { (Milyon TL) }\end{array}$} & \multirow{2}{*}{$\begin{array}{l}\text { Net Kar } \\
\text { (Milyon } \\
\text { TL) }\end{array}$} & \multirow{2}{*}{$\begin{array}{l}\text { Net } \\
\text { Satışlar } \\
\text { (Milyon } \\
\text { TL) }\end{array}$} & \\
\hline & & & & & & & \\
\hline 1 & ANADOLU EFES & 17.560 & 45.898 & 21.518 & 1.309 & 23.077 & 13.666 \\
\hline 2 & AVOD & 346 & 271 & 178 & 17 & 179 & 167 \\
\hline 3 & BANVITT & 4.556 & 2.048 & 954 & 111 & 3.439 & 1.857 \\
\hline 4 & COCA-COLA İÇECEK & 8.221 & 15.960 & 8.590 & 942 & 12.245 & 9.844 \\
\hline 5 & DARDANEL & 828 & 171 & 446 & 5 & 519 & 202 \\
\hline 6 & EKİZ KİMYA & 10 & 47 & 37 & 3 & 58 & 4 \\
\hline 7 & ERSU & 31 & 27 & 17 & 3 & 10 & 75 \\
\hline 8 & FRIGO-PAK & 386 & 89 & 57 & 11 & 81 & 78 \\
\hline 9 & KENT GIDA & 1.042 & 870 & 409 & 25 & 1.022 & 5.094 \\
\hline 10 & KEREVITTAŞ & 1.736 & 2.723 & 1.757 & 159 & 2.493 & 2.158 \\
\hline 11 & KONFRUT GIDA & 168 & 306 & 169 & 19 & 182 & 258 \\
\hline 12 & KRISTAL KOLA & 93 & 168 & 46 & 1 & 145 & 145 \\
\hline 13 & MERKO GIDA & 96 & 86 & 64 & -16 & 67 & 62 \\
\hline 14 & OYLUM & 154 & 62 & 35 & 2 & 55 & 70 \\
\hline 15 & PENGUEN GIDA & 375 & 377 & 204 & -8 & 176 & 115 \\
\hline 16 & PINAR ENTEGRE & 751 & 850 & 195 & 46 & 748 & 397 \\
\hline 17 & PINAR SU & 406 & 325 & 274 & -33 & 225 & 104 \\
\hline 18 & PINAR SÜT & 1.033 & 1.549 & 651 & 35 & 1.665 & 570 \\
\hline 19 & SELÇUK GIDA & 44 & 33 & 8 & 3 & 16 & 19 \\
\hline 20 & TAT GIDA & 1.061 & 1.026 & 466 & 72 & 1.142 & 855 \\
\hline 21 & TAZE KURU & 33 & 7 & 6 & -1 & 3 & 7 \\
\hline 22 & TUKAŞ GIDA & 886 & 807 & 526 & 107 & 641 & 3.367 \\
\hline 23 & TÜRK TUBORG & 1.434 & 2.535 & 1.229 & 437 & 2.171 & 3.838 \\
\hline 24 & ULUSOY UN & 243 & 1.280 & 1.007 & 27 & 3.052 & 323 \\
\hline 25 & ÜLKER BİSKÜVİ & 9.000 & 12.792 & 7.858 & 1.011 & 7.803 & 7.647 \\
\hline
\end{tabular}


VZA Verimlilik Skorlart ve Emsal Firma/Lamda Değerleri

\begin{tabular}{|l|l|l|c|}
\hline Sıra & Firma Adı & Verimlilik Skoru & Emsal Firmalar ve Lamda Değerleri \\
\hline 1 & ANADOLU EFES & $100,00 \%$ & \\
\hline 2 & AVOD & $52,20 \%$ & $5(0,04) 21(0,90) 23(0,04) 24(0,02)$ \\
\hline 3 & BANVIT & $100,00 \%$ & \\
\hline 4 & COCA-COLA İÇECEK & $100,00 \%$ & \\
\hline 5 & DARDANEL & $100,00 \%$ & \\
\hline 6 & EKİ KIMYA & $100,00 \%$ & \\
\hline 7 & ERSU & $100,00 \%$ & \\
\hline 8 & FRİGO-PAK & $94,80 \%$ & $5(0,03) 21(0,94) 23(0,03) 24(0,00)$ \\
\hline 9 & KENT GIDA & $74,50 \%$ & $3(0,12) 16(0,25) 19(0,49) 24(0,14)$ \\
\hline 10 & KEREVİTAŞ & $57,80 \%$ & $5(0,09) 21(0,02) 23(0,33) 24(0,57)$ \\
\hline 11 & KONFRUT GIDA & $50,70 \%$ & $6(0,34) 19(0,56) 21(0,04) 23(0,03) 24(0,03)$ \\
\hline 12 & KRİSTAL KOLA & $100,00 \%$ & \\
\hline 13 & MERKO GIDA & $41,70 \%$ & $3(0,00) 19(0,10) 21(0,88) 24(0,02)$ \\
\hline 14 & OYLUM & $63,80 \%$ & $19(0,45) 21(0,54) 23(0,00) 24(0,01)$ \\
\hline 15 & PENGUEN GIDA & $28,60 \%$ & $3(0,01) 16(0,00) 19(0,95) 24(0,04)$ \\
\hline 16 & PINAR ENTEGRE & $100,00 \%$ & \\
\hline 17 & PINAR SU & $30,30 \%$ & $5(0,02) 21(0,91) 24(0,07)$ \\
\hline 18 & PINAR SÜT & $77,90 \%$ & $3(0,06) 16(0,61) 24(0,33)$ \\
\hline 19 & SELÇUK GIDA & $100,00 \%$ & \\
\hline 20 & TAT GIDA & $84,40 \%$ & $3(0,11) 16(0,29) 19(0,40) 23(0,10) 24(0,11)$ \\
\hline 21 & TAZE KURU & $100,00 \%$ & \\
\hline 22 & TUKAŞ GIDA & $81,60 \%$ & $5(0,21) 21(0,54) 23(0,24)$ \\
\hline 23 & TÜRK TUBORG & $100,00 \%$ & \\
\hline 24 & ULUSOY UN & $100,00 \%$ & \\
\hline 25 & ÜLKER BİSKÜVİ & $100,00 \%$ & \\
\hline
\end{tabular}

